\title{
Effect of acupuncture on intraocular pressure and tear production in healthy horses
}

\author{
Thiene de Lima Rodrigues ${ }^{*}$ (i) Luiz Leite dos Santos Neto $^{2}$ (i) \\ Vital Henrique de Lira Silva ${ }^{2}$ (D) Alexandra Melo Oliveira ${ }^{1}$ (D) \\ Péricles de Farias Borges ${ }^{3}$ (D) Ivia Carmem Talieri² (D) Danila Barreiro Campos ${ }^{1,2}$ (D)
}

\begin{abstract}
${ }^{1}$ Programa de Pós-graduação em Ciência Animal, Centro de Ciências Agrárias, Universidade Federal da Paraíba (UFPB), 58397-000, Areia, PB, Brasil. E-mail: thiene.rodrigues@hotmail.com. *Corresponding author.

${ }^{2}$ Departamento de Ciências Veterinárias, Centro de Ciências Agrárias, Universidade Federal da Paraíba (UFPB), Areia, PB, Brasil.

${ }^{3}$ Departamento de Ciências Fundamentais e Sociais, Centro de Ciências Agrárias, Universidade Federal da Paraíba (UFPB), Areia, PB, Brasil.
\end{abstract}

\begin{abstract}
Acupuncture is an ancient Chinese form of therapy that involves needle stimulation of specific points on the body for therapeutic and homeostatic effects. In ophthalmology, acupuncture helps as a conventional or adjuvant therapy for numerous eye disorders, including myopia, strabismus, dry eye, and cataracts. This study aimed to evaluate the effect of acupuncture on tear production (TP) and intraocular pressure (IOP) in horses. Ten healthy horses, females and males with ages varying between eight months and nine years, were used. Schirmer's I test and applanation tonometry were used to evaluate the basal TP and IOP of both eyes. The measurements were taken immediately before (T10) the insertion of the needles and 5 (T5), 15 (T15), 30 (T30) and 60 (T60) minutes and 24 (T24) hours after a 20-minute acupuncture session. Mean values of both eyes were analyzed over time. TP increased in 50\% of the animals at T5, T15 and T24, in 30\% at T30, and in $40 \%$ at T60, with an increase of up to $8.5 \mathrm{~mm} / \mathrm{min}$ at T15 and T60. In addition, there was a significant difference between T24 and T30, with a $14.1 \%$ increase in TP at T24. Meanwhile, IOP decreased in 50\% of the animals at T5 and T30, in 20\% at T15, in 60\% at T60, and in 70\% at T24. Thus, we suggest that acupuncture is a technique that can benefit horses with diseases that alter these parameters, either alone or as an adjunct in conventional therapeutic protocols.
\end{abstract}

Key words: acupoints, applanation tonometry, Schirmer's I test.

Efeito da acupuntura sobre a pressão intraocular e a produção lacrimal em equinos hígidos

RESUMO: A acupuntura é uma terapia milenar de origem chinesa que funciona através da estimulação de pontos especificos do corpo com agulhas, visando efeitos terapêuticos e homeostáticos. Na área de oftalmologia a acupuntura tem auxiliado como terapia convencional ou adjuvante de inúmeras afecções oculares, incluindo miopia, estrabismo, olho seco, catarata, entre outras. Esse estudo teve como propósito avaliar o efeito da acupuntura no comportamento da produção lacrimal e da pressão intraocular em equinos. Utilizou-se 10 equinos hígidos, fêmeas e machos, com idades variando entre oito meses e nove anos. O teste lacrimal de Schirmer tipo I e da tonometria de aplanação foram utilizados para avaliar a produção basal de lágrima (PL) e a pressão intraocular (PIO) de ambos os olhos. As aferições foram realizadas imediatamente antes da inserção das agulhas (T0) e cinco (T5), 15 (T15), 30 (T30) e 60 (T60) minutos e 24 (T24) horas após sessão de acupuntura de 20 minutos. Os valores obtidos foram analisados quanto ao seu comportamento ao longo do tempo, utilizando-se a média dos dois olhos de cada animal. A PL aumentou em 50\% dos animais em T5, T15 e T24, 30\% dos animais em T30 e 40\% dos animais em T60, com aumento de até $8,5 \mathrm{~mm} / \mathrm{min}$ em T15 e T60. Além disso, observou-se diferença significativa entre o T24 e o T30 ( $p=0,0128)$, com aumento de 14,1\% na PL no T24. Com relação à PIO, notou-se que 50\% dos animais sofreram redução na pressão em T5 e T30, $20 \%$ dos animais redução em T15, 60\% dos animais em T60 e 70\% dos animais apresentaram redução em T24. A estimulação dos acupontos relacionados ao sistema visual foi capaz de aumentar a produção lacrimal e diminuir a pressão intraocular em equinos sadios. Dessa maneira, sugere-se que a acupuntura é uma técnica que poderá trazer benefícios a cavalos portadores de doenças que cursam com a alteração desses parâmetros, tanto quando empregada isoladamente, como quando adjuvante a protocolos terapêticos convencionais.

Palavras-chave: acupontos, tonometria de aplanação, teste lacrimal de Schirmer.

\section{INTRODUCTION}

Acupuncture is a therapeutic modality based on traditional Chinese medicine (TCM) (RHEE et al., 2002). It has been used in the West as an adjunct in the treatment of several diseases. Initially, acupuncture was practiced on animals with a prominent role in agriculture and warfare, such as horses. Subsequently, other animals and humans began to benefit from acupuncture (LIN et al., 2003; KIM, Y. et al., 2005).

The acupuncture technique consists of applying needles to specific points on the body (LIN, 2006; ERNST et al., 2007). The stimulation 
of these points, which act on all regions of the body, provides therapeutic and homeostatic effects (FARIA \& SCOGNAMILLO-SZABÓ, 2008), with the relief of symptoms through the reorganization of the body's energy (CHU \& POTTER, 2002; MACIOCIA, 2007). Acupuncture can be indicated for pain control (LUNA, 2002), vertebral traumas, intervertebral disc disease, idiopathic Horner syndrome (CHO \& KIM, 2008), and other conditions, including those of an ocular nature (BENSKY, 1981; ERNST et al., 2007).

The ophthalmic effects of acupuncture were described in several studies. In humans, it can be potentially useful in the treatment of several eye conditions, including keratoconjunctivitis sicca (KCS), myopia, paralytic strabismus, retinitis pigmentosa, optic atrophy, iritis, conjunctivitis, cataracts (TAYLOR, 2001), and glaucoma (KURUSU et al., 2005). In 1999, the American Academy of Ophthalmology recognized acupuncture as an adjunct in the conventional treatment of certain ophthalmic conditions (KURUSU et al., 2005).

Ophthalmic diseases are common in veterinary medicine; those related to tear production (TP), such as keratoconjunctivitis sicca (KCS), and those that alter intraocular pressure (IOP), such as glaucoma (SILVA et al., 2015), are quite common. Although KCS and glaucoma are not common in horses (CRISPIN, 2000; GHAFFARI et al., 2009; MCLELLAN \& ARCHER, 2000), the successful treatment of these conditions is essential for maintaining these animals' quality of life, since the absence of vision in even one eye affects the behavior of horses.

In $\mathrm{KCS}$, lacrimal hyposecretion greatly affects the health of the ocular surface, causing keratitis and conjunctivitis. In advanced cases, there may be formation of corneal ulcers and scars, and new vessels and corneal pigmentation may occur (GRAHN \& STOREY, 2004). The pre-corneal tear film, which is evenly distributed through the eyelid incursions, is an essential component of the eyes as it maintains the entire ocular surface's stability and health (TSENG et al., 2006). Tears remove foreign bodies and dirt from the conjunctival sacs and the cornea, provide nutrition and oxygenation to the cornea, and prevent infections through antimicrobial agents (CASTILLO, 2012)

Glaucoma results from the imbalance of homeostasis between the production and drainage of aqueous humor, resulting in IOP values beyond normal reference values BAUM et al., 1995). Aqueous humor provides trophic support for the removal of metabolic residues from the cornea and the lens (CHI-
HO et al., 2002). After aqueous humor is formed by the ciliary body in the posterior chamber, the aqueous humor goes to the anterior chamber. It is drained in two ways: through the corneal-scleral junction or the iridocorneal angle via the vorticose and episcleral veins and through the uveoscleral pathway, which is the least significant pathway (SMITH et al., 1986)

The treatment of tear hyposecretion aims to increase TP, and the treatment of glaucoma aims to reduce IOP. Both conditions are initially treated with eye drops, requiring several applications during the day or even surgery in case of failure of clinical treatment, with the possibility that these treatments may not be fully effective, making processes chronic (PETERS et al., 2013). Therefore, it is necessary to search for alternative treatment methods to help manage these conditions.

This study aimed to evaluate the shortterm effects of acupoints related to the visual system on TP and IOP in healthy horses. The behaviors of these two physiological parameters are highly relevant in veterinary ophthalmology as they will determine whether acupuncture can be associated with conventional therapeutic protocols in cases of $\mathrm{KCS}$ and glaucoma in horses.

\section{MATERIALS AND METHODS}

\section{Animals}

Ten horses, five females and five males aged between eight months and nine years and belonging to two farms in the municipality of Areia, Brejo Paraibano, Brazil, were used. The research was previously approved by the Ethics Committee on the Use of Animals at the Federal University of Paraíba (Comissão de Ética no Uso de Animais da Universidade Federal da Paraiba [CEUA/UFPB]) under protocol No. 7328131119/2019.

The healthy animals were selected through general physical and ophthalmic examinations, which were performed one week before the beginning of the research. The ophthalmic examination consisted of menace reflex; direct and consensual pupillary light reflex; Schirmer's tear test (DrogaVETLabs, Curitiba PR); applanation tonometry (Tono-Pen AVIA $^{\circledR}$, Reichert, Reichert Technologies, New York, USA) after administering topical anesthesia (Anestalcon ${ }^{\circledR}$, Alcon, NOVARTIS BIOCIÊNCIAS SA, São Paulo$\mathrm{SP}$ ); examination of the orbits, eyelids and third eyelids, conjunctivas, anterior chambers, pupils, irises, lens, and vitreous; and indirect ophthalmoscopy (Eyetc Equipamentos Oftalmoscópicos, IND. WITH. LTDA, São Carlos, São Paulo-SP). 


\section{Experimental design}

The acupoints were selected according to Western medicine-based disease and imbalance patterns targeting the visual system. Needle insertion was performed at Tai-yang, TH-23 (Si-zhu-kong), BL-2 (Cuan-zhu), GB-20 (Feng-chi), LI-4 (He-gu), BL-18 (Gan-shu), BL-23 (Shen-shu), LIV-3 (Taichong), ST-36 (Hou-san-li), and GB-37 (Guang-ming) points (Figures 1 and 2) (SILVA et al., 2015; XIE \& PREAST, 2007). Disposable Chinese acupuncture needles $(25 \times 15 \mathrm{~mm}$; Spring C, Masterminds Ltda. $)$ were inserted in a bilateral-oblique direction toward the skin up to a depth of $0.5-0.8 \mathrm{~cm}$. The needles were not manipulated during and after insertion, and the stimulation time was 20 minutes.

IOP and TP were assessed in both eyes of each the 10 animals studied. The animals each received two acupuncture sessions with an interval of 15 days between them. TP was measured in the first session, and IOP was measured in the second session. The measurements were performed before (T0) the application of the needles and at 5 (T5), 15 (T15), 30 (T30), and 60 (T60) minutes and 24 (T24) hours after removing the needles.

Sterile filter paper strips were used to measure TP (Schirmer's tear test; DrogaVET
Labs, Curitiba - PR). IOP was measured using applanation tonometry (Tono-Pen AVIA ${ }^{\circledR}$, Reichert, Reichert Technologies) two minutes after corneal desensitization with anesthetic proxymetacaine hydrochloride-based $5 \mathrm{mg} / \mathrm{ml}$ eye drops (Anestalcon ${ }^{\circledR}$, Alcon, Novartis Biociências SA, São Paulo-SP). Only values with a confidence level of $95 \%$ were considered (Figure 2).

\section{Data analysis}

The data were entered into a Microsoft Excel 2002 spreadsheet. A descriptive analysis of the mean of the right and left eyes of each animal was performed at each time for the values of Schirmer's tear test and IOP and the behavior of both over time.

Statistical evaluation was performed using analysis of variance (ANOVA) to determine the effect of the stimulation time on the mean values. The means were compared using the Tukey test, with a significance level of $0.05(P<0.05)$.

\section{RESULTS}

The mean (TP) after stimulation of the acupoints varied at all times in relation to the baseline values (T0). There were no significant differences

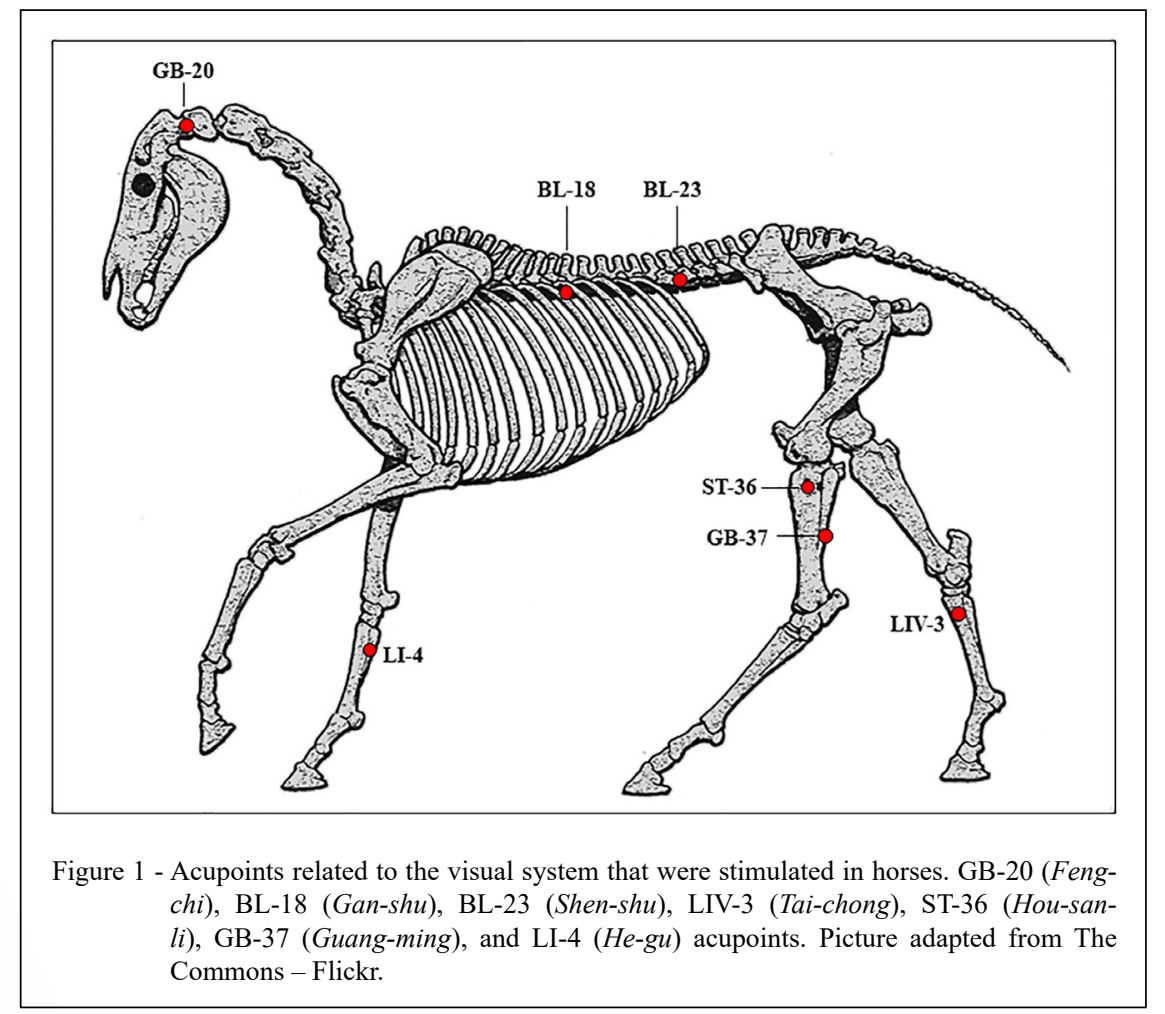

Ciência Rural, v.52, n.1, 2022. 


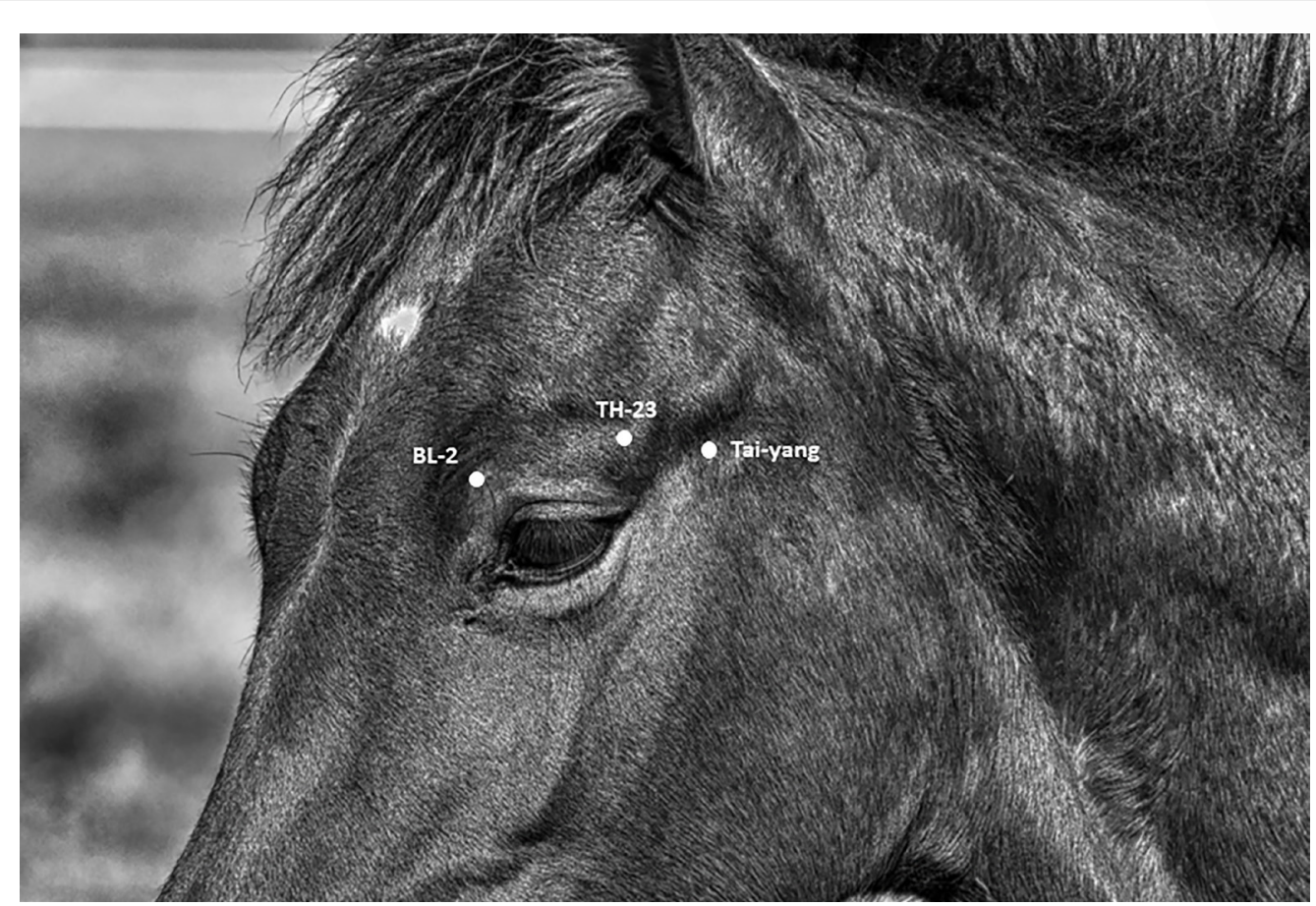

Figure 2 - Acupoints related to the visual system that were stimulated in horses. Tai-yang, TH-23 (Si-zhu-kong), and BL-2 (Cuan-zhu) acupoints. Picutre adapted from Pixabay.

between the mean times and $\mathrm{T} 0$ and between the right and left eyes. However, an increase in TP was observed in $50 \%$ of the animals at $\mathrm{T} 5, \mathrm{~T} 15$, and $\mathrm{T} 24$. This increase ranged from $10 \%$ to $46.4 \%(+2.0 \mathrm{~mm} /$ $\min$ to $6.5 \mathrm{~mm} / \mathrm{min})$ at $\mathrm{T} 5,8.9 \%$ to $35.7 \%(+2.0 \mathrm{~mm} /$ $\min$ to $5.0 \mathrm{~mm} / \mathrm{min}$ ) at $\mathrm{T} 15$, and $5.6 \%$ to $42.5 \%$ (+ $1.0 \mathrm{~mm} / \mathrm{min}$ to $8.5 \mathrm{~mm} / \mathrm{min}$ ) at T24. A $2.9 \%$ to $20 \%$ increase $(+0.5 \mathrm{~mm} / \mathrm{min}$ to $4.0 \mathrm{~mm} / \mathrm{min})$ in TP was observed in $30 \%$ of animals at $\mathrm{T} 30$. At $\mathrm{T} 60,40 \%$ of the animals showed a $5.7 \%$ to $60.7 \%$ increase in TP $(+1.0 \mathrm{~mm} / \mathrm{min}$ to $8.5 \mathrm{~mm} / \mathrm{min}$; Tables 1 and 2$)$. There was a significant difference between T24 and T30 $(P=0.0128)$ when the treatment times were compared, with an increase of $14.1 \%$ in TP at T24.

The mean IOP varied according to the treatment times for each animal in relation to T0 and there was no significant difference between the means of the right and left eyes. A reduction in IOP was observed in $50 \%$ of the animals at T5 and T30, representing a decrease of $3.7 \%$ to $31.7 \%$ (- 1.0 $\mathrm{mmHg}$ to $9.5 \mathrm{mmHg}$ ) at $\mathrm{T} 5$ and $1.8 \%$ to $25.9 \%$ (- 0.5 $\mathrm{mmHg}$ to $7.5 \mathrm{mmHg}$ ) at T30. At T15, the IOP of two animals decreased, with one horse showing a $26.7 \%$ decrease $(-8 \mathrm{mmHg})$ and the other a $14.5 \%$ decrease
(- $4 \mathrm{mmHg}$ ). A reduction of $5.0 \%$ to $20.0 \%$ in IOP was observed in $60 \%$ of the animals at T60, corresponding to a $1.5 \mathrm{mmHg}$ to $5.5 \mathrm{mmHg}$ reduction in relation to T0. At T24, 70\% of the horses showed a reduction of $0.5 \mathrm{mmHg}$ to $10.5 \mathrm{mmHg}$ ( $1.9 \%$ to $36.2 \%)$ in IOP (Tables 3 and 4). There was no significant difference when the times after treatment were compared to T0 or with each other $(P>0.05)$.

\section{DISCUSSION}

Acupuncture is a TCM technique used to treat several diseases (BENSKY, 1981). In Western medicine, it is widely used as adjunctive therapy to allopathic treatments (CARIELLO et al., 2006; CHO \& KIM, 2008; CHU \& POTTER, 2002; KIM, Y. et al. 2005). The therapeutic effects of acupuncture are observed throughout the body, and several studies have shown its advantageous effects on several conditions in the visual system (ERNST, 2006), including KCS (ELIASON et al., 2007) and glaucoma (KURUSU et al., 2005). In this study, increased TP was observed in $50 \%$ of horses 24 hours after the acupuncture session, which is the time with 
Table 1 - Mean and standard deviation of the values obtained with Schirmer's tear test (in $\mathrm{mm} / \mathrm{min}$ ) in both eyes of each of the 10 horses (AN1-AN10) before insertion of the needles (T0) and at 5 (T5), 15 (T15), 30 (T30), and 60 (T60) minutes and 24 (T24) hours after stimulation of the Tai-yang, TH-23 (Si-zhu-kong), BL-2 (Suan-zhu), GB-20 (Feng-chi), LI-4 (He-gu), BL-18 (Gan-shu), BL-23 (Shen-shu), LIV-3 (Tai-chong), ST-36 (Hou-san-li), and GB-37 (Guang-ming) acupoints.

\begin{tabular}{lcccccc}
\hline & T0 & T5 & T15 & T30 & T60 \\
\hline AN1 & $18.0 \pm 2.8$ & $18.0 \pm 1.4$ & $14.0 \pm 1.4$ & $16.0 \pm 1.4$ & $14.5 \pm 3.5$ & $19.0 \pm 1.4$ \\
AN2 & $22.5 \pm 2.1$ & $15.0 \pm 5.7$ & $12.0 \pm 2.8$ & $14.0 \pm 0.0$ & $14.5 \pm 0.7$ & $17.5 \pm 3.5$ \\
\hline AN3 & $17.5 \pm 3.5$ & $21.5 \pm 6.4$ & $16.5 \pm 12.0$ & $18.0 \pm 4.2$ & $18.5 \pm 0.7$ & $17.5 \pm 3.5$ \\
AN4 & $16.0 \pm 0.0$ & $19.0 \pm 2.8$ & $19.0 \pm 4.2$ & $15.5 \pm 0.7$ & $12.5 \pm 2.1$ & $15.5 \pm 2.1$ \\
\hline AN5 & $21.0 \pm 1.4$ & $14.5 \pm 0.7$ & $19.5 \pm 0.7$ & $16.0 \pm 0.0$ & $23.5 \pm 4.9$ & $20.5 \pm 3.5$ \\
AN6 & $22.5 \pm 4.9$ & $13.5 \pm 0.7$ & $24.5 \pm 0.7$ & $20.5 \pm 4.9$ & $21.0 \pm 0.0$ & $24.5 \pm 3.5$ \\
AN7 & $21.0 \pm 1.4$ & $25.0 \pm 1.4$ & $24.5 \pm 7.8$ & $22.5 \pm 6.4$ & $21.0 \pm 4.2$ & $24.5 \pm 3.5$ \\
AN8 & $14.0 \pm 0.0$ & $20.5 \pm 3.5$ & $19.0 \pm 1.4$ & $13.0 \pm 1.4$ & $22.5 \pm 0.7$ & $15.0 \pm 1.4$ \\
\hline AN9 & $20.0 \pm 5.7$ & $22.0 \pm 4.2$ & $23.5 \pm 6.4$ & $24.0 \pm 1.4$ & $26.5 \pm 4.9$ & $28.5 \pm 2.1$ \\
AN10 & $19.5 \pm 0.7$ & $15.5 \pm 0.7$ & $14.0 \pm 5.7$ & $17.0 \pm 1.4$ & $16.5 \pm 2.1$ & $19.0 \pm 0.0$ \\
\hline Mean \pm SD & $19.2 \pm 2.8$ & $18.5 \pm 3.8$ & $18.7 \pm 4.5$ & $17.7 \pm 3.6^{*}$ & $19.1 \pm 4.5$ & $20.2 \pm 4.4^{*}$ \\
\hline
\end{tabular}

${ }^{*}$ statistically different means $(\mathrm{P}<0.05)$.

the highest production among the analyzed times. The gradual increase in TP was also observed in beagles (SILVA et al., 2015) and rabbits (GONG $\&$ SUN, 2007) using points BL-2, TH-23, and Taiyang, the same periocular points as those stimulated in the horses of this study. The increased secretory activity of the lacrimal gland has been described histologically by Gong and Sun (2007). The theoretical bases of TCM describe that the effects of acupuncture are due to the balance of body energy, which can enhance or restore the normal function of an organ or system (SCOGNAMILLO-

Table 2 - Variation of the values obtained with Schirmer's tear test (in $\mathrm{mm} / \mathrm{min}$ and \%) in both eyes of each of the 10 horses (AN1AN10) at 5 (T5), 15 (T15), 30 (T30), and 60 (T60) minutes and 24 (T24) hours in relation to T0 after stimulation of the Taiyang, TH-23 (Si-zhu-kong), BL-2 (Suan-zhu), GB-20 (Feng-chi), LI-4 (He-gu), BL-18 (Gan-shu), BL-23 (Shen-shu), LIV-3 (Tai-chong), ST-36 (Hou-san-li), and GB-37 (Guang-ming) acupoints.

\begin{tabular}{|c|c|c|c|c|c|c|}
\hline & $\mathrm{T} 0$ & $\mathrm{~T} 5$ & $\mathrm{~T} 15$ & $\mathrm{~T} 30$ & $\mathrm{~T} 60$ & $\mathrm{~T} 24$ \\
\hline AN1 & 18.0 & - & $-4.0(22.2 \%)$ & - $2.0(11.1 \%)$ & - 3,5 (19.4\%) & $+1.0(5.6 \%)$ \\
\hline AN2 & 22.5 & $-7.5(33.3 \%)$ & $-10.5(46.7 \%)$ & $-8.5(37.8 \%)$ & $-8.0(35.6 \%)$ & $-5.0(22.2 \%)$ \\
\hline AN3 & 17.5 & $+4.0(22.9 \%)$ & $-1.0(5.7 \%)$ & $+0.5(2.9 \%)$ & $+1.0(5.7 \%)$ & - \\
\hline AN4 & 16.0 & $+3.0(18.8 \%)$ & $+3.0(18.8 \%)$ & $-0.5(3.1 \%)$ & $-3.5(21.9 \%)$ & $-0.5(3.1 \%)$ \\
\hline AN5 & 21.0 & $-6.5(31.0 \%)$ & $-1.5(7.1 \%)$ & $-5.0(23.8 \%)$ & $+2.5(11.9 \%)$ & $-0.5(2.4 \%)$ \\
\hline AN6 & 22.5 & $-9.0(40.0 \%)$ & $+2.0(8.9 \%)$ & $-2.0(8.9 \%)$ & $-1.0(6.7 \%)$ & $+2.0(8.9 \%)$ \\
\hline AN7 & 21.0 & $+4.0(19.0 \%)$ & $+3.5(16.7 \%)$ & $+1.5(7.1 \%)$ & - & $+3.5(16.7 \%)$ \\
\hline AN8 & 14.0 & $+6.5(46.4 \%)$ & $+5.0(35.7 \%)$ & $-1.0(7.1 \%)$ & $+8.5(60.7 \%)$ & $+1.0(7.1 \%)$ \\
\hline AN9 & 20.0 & $+2.0(10.0 \%)$ & $+3.5(17.5 \%)$ & $+4.0(20.0 \%)$ & $+6.5(32.5 \%)$ & $+8.5(42.5 \%)$ \\
\hline AN10 & 19.5 & $-4.0(20.5 \%)$ & $-5,5(28.2 \%)$ & $-2.5(12.8 \%)$ & $-3.0(15.4 \%)$ & $-0.5(2.6 \%)$ \\
\hline
\end{tabular}

$(+)$ increase in relation to T0; (-) decrease in relation to T0. 
Table 3 - Mean intraocular pressure (in $\mathrm{mmHg}$ ) in both eyes of each of the 10 horses (AN1 - AN10) before insertion of the needles (T0) and at 5 (T5), 15 (T15), 30 (T30), and 60 (T60) minutes and 24 (T24) hours after stimulation of Tai-yang, TH-23 (Si-zhu-kong), BL-2 (Suan-zhu), GB-20 (Feng-chi), LI-4 (He-gu), BL-18 (Gan-shu), BL-23 (Shen-shu), LIV-3 (Tai-chong), ST-36 (Hou-sanli), and GB-37 (Guang-ming) acupoints.

\begin{tabular}{lcccccc}
\hline & T0 & T5 & T15 & T30 & T60 \\
\hline AN1 & $21.0 \pm 2.8$ & $23.0 \pm 2.8$ & $22.0 \pm 4.2$ & $24.5 \pm 4.9$ & $21.0 \pm 1.4$ & $22.5 \pm 0.7$ \\
AN2 & $30.0 \pm 0.0$ & $20.5 \pm 2.1$ & $22.0 \pm 0.0$ & $35.0 \pm 14.1$ & $28.5 \pm 9.2$ & $23.0 \pm 0.0$ \\
\hline AN3 & $22.5 \pm 4.9$ & $27.5 \pm 10.6$ & $27.0 \pm 9.9$ & $22.0 \pm 2.8$ & $18.5 \pm 0.7$ & $21.0 \pm 4.2$ \\
AN4 & $22.5 \pm 3.5$ & $20.5 \pm 3.5$ & $31.5 \pm 12.0$ & $22.5 \pm 0.7$ & $20.0 \pm 1.4$ & $22.0 \pm 1.4$ \\
AN5 & $21.0 \pm 2.8$ & $25.5 \pm 14.8$ & $22.5 \pm 10.6$ & $26.0 \pm 1.4$ & $30.5 \pm 17.7$ & $21.0 \pm 4.2$ \\
AN6 & $27.5 \pm 2.1$ & $28.0 \pm 11.3$ & $28.0 \pm 0.0$ & $25.5 \pm 3.5$ & $23.5 \pm 2.1$ & $18.0 \pm 4.2$ \\
\hline AN7 & $27.5 \pm 3.5$ & $26.0 \pm 5.7$ & $23.5 \pm 4.9$ & $27.0 \pm 4.2$ & $22.0 \pm 2.8$ & $22.5 \pm 3.5$ \\
AN8 & $29.0 \pm 4.2$ & $27.0 \pm 7.1$ & $33.5 \pm 0.7$ & $21.5 \pm 2.1$ & $25.5 \pm 3.5$ & $18.5 \pm 0.7$ \\
\hline AN9 & $26.5 \pm 3.5$ & $25.0 \pm 4.2$ & $31.5 \pm 2.1$ & $23.5 \pm 6.4$ & $27.5 \pm 0.7$ & $26.0 \pm 2.8$ \\
AN10 & $23.5 \pm 9.2$ & $32.0 \pm 2.8$ & $26.5 \pm 14.8$ & $33.0 \pm 7.1$ & $24.5 \pm 9.2$ & $26.0 \pm 2.8$ \\
\hline Mean ( \pm SD) & $25.1 \pm 3.4$ & $25.5 \pm 3.5$ & $26.8 \pm 4.3$ & $26.1 \pm 4.6$ & $24.2 \pm 3.9$ & $22.1 \pm 2.7$ \\
\hline
\end{tabular}

SZABÓ \& BECHARA, 2010). Moreover, one must consider the proximity of periocular acupoints to areas innervated by the trigeminal and facial nerves (HAMOR et al., 2005). The trigeminal nerve provides sensitivity to periocular structures, the eyeball, and the lacrimal gland. Stimulation of the trigeminal nerve could reflexively stimulate TP controlled by parasympathetic fibers of the facial nerve (SILVA et al., 2015).

The stimulation of acupoints related to the visual system can reduce IOP values, especially after 24 hours. It is believed that the reduction in IOP may be associated with a decrease in blood pressure and an increase in endorphin release

Table 4 - Variation of intraocular pressure values (in mmHg and \%) in both eyes of each of the 10 horses (AN1-AN10) at 5 (T5), 15 (T15), 30 (T30), and 60 (T60) minutes and 24 (T24) hours in relation to T0 after stimulation of Tai-yang, TH-23 (Si-zhu-kong), BL-2 (Suan-zhu), GB-20 (Feng-chi), LI-4 (He-gu), BL-18 (Gan-shu), BL-23 (Shen-shu), LIV-3 (Tai-chong), ST-36 (Hou-sanli), and GB-37 (Guang-ming) acupoints.

\begin{tabular}{lcccccc}
\hline & T0 & T5 & T15 & T30 & T60 & T24 \\
\hline AN1 & 21.0 & $+2.0(9.5 \%)$ & $+1,0(4.8 \%)$ & $+3.5(16.7 \%)$ & - & $+1.5(7.1 \%)$ \\
\hline AN2 & 30.0 & $-9.5(31.7 \%)$ & $-8.0(26.7 \%)$ & $+5.0(16.7 \%)$ & $-1.5(5.0 \%)$ & $-7.0(23.3 \%)$ \\
\hline AN3 & 22.5 & $+5.0(22.2 \%)$ & $+4.5(20.0 \%)$ & $-0.5(2.2 \%)$ & $-4.0(17.3 \%)$ & $-1.5(6.7 \%)$ \\
\hline AN4 & 22.5 & $-2.0(8.9 \%)$ & $+9.0(40.0 \%)$ & - & $-2.5(11.1 \%)$ & $-0.5(2.2 \%)$ \\
\hline AN5 & 21.0 & $+4.5(21.4 \%)$ & $+1.5(7.1 \%)$ & $+5.0(23.8 \%)$ & $+9.5(45.2 \%)$ & - \\
AN6 & 27.5 & $+0.5(1.8 \%)$ & $+0.5(1.8 \%)$ & $-2.0(7.3 \%)$ & $-4.0(14.5 \%)$ & $-9.5(34.5 \%)$ \\
\hline AN7 & 27.5 & $-1.5(5.5 \%)$ & $-4.0(14.5 \%)$ & $-0.5(1.8 \%)$ & $-5.5(20.0 \%)$ & $-5.0(18.2 \%)$ \\
AN8 & 29.0 & $-2.0(6.9 \%)$ & $+4.5(15.5 \%)$ & $-7.5(25.9 \%)$ & $-3.5(12.1 \%)$ & $-10.5(36.2 \%)$ \\
\hline AN9 & 26.5 & $-1.0(3.7 \%)$ & $+5.0(18.9 \%)$ & $-3.0(11.3 \%)$ & $+1.0(3.8 \%)$ & $-0.5(1.9 \%)$ \\
\hline AN10 & 23.5 & $+8.5(36.2 \%)$ & $+3.0(12.8 \%)$ & $+9.5(40.4 \%)$ & $+1.0(4.3 \%)$ & $+2.5(10.6 \%)$ \\
\hline
\end{tabular}

$(+)$ increase in relation to $\mathrm{T} 0$; (-) decrease in relation to $\mathrm{T} 0$. 
(KURUSU et al., 2005), as well as a reduction in the rate of aqueous humor formation resulting from the decrease in norepinephrine (CHU \& POTTER, 2002; TANGJITJAROEN et al., 2009; ULETT et al., 1998) and dopamine levels (CHU \& POTTER, 2002). Conversely, a decrease in IOP without changes in the cardiovascular parameters was observed in dogs anesthetized with isoflurane and treated with electroacupuncture (KIM, M. et al., 2005), which, according to TCM, may occur due to the energetic reorganization of the animal organism.

The stimulation of the LI-4, LIV-3, and GB37 points promoted a decrease in IOP in dogs (KIM, M. et al., 2005). In this study, IOP measurements were taken up to 60 minutes after the acupuncture session. Here, although $60 \%$ of the horses showed a reduction in IOP after 60 minutes of stimulation of the points, most animals showed a reduction in IOP 24 hours after the acupuncture session. In fact, the effects of the stimulation of the points persisted for weeks. Kurusu et al. (2005), using acupuncture in human patients with glaucoma, observed a significant reduction in IOP values for four weeks. Future studies are needed to determine the duration of the effects after an acupuncture session in horses.

A study with humans showed that electroacupuncture improved the symptoms of dry eye in $88 \%$ of patients (ELIASON et al., 2007). In addition to reducing IOP in humans with glaucoma, the study by Kurusu et al. (2005) demonstrated that acupuncture therapy improved visual acuity. The changes resulting from the increase in TP and decrease in IOP in healthy horses as observed in this study, especially after 24 acupuncture sessions, were associated with the results observed in humans affected by visual disorders and suggested that the stimulation of acupoints related to the visual system may also contribute to the treatment and management of eye diseases in horses. Thus, studies should be conducted with sick animals to assess the effect of the therapy in this condition.

\section{CONCLUSION}

The study demonstrated that the stimulation of acupoints related to the visual system increases TP and decreases IOP in healthy horses in the short term. Thus, it is suggested that acupuncture can be beneficial to horses with diseases that change these parameters, when used alone or as an adjuvant to conventional therapeutic protocols.

Further studies should be conducted with animals with clinical signs of the ophthalmic diseases discussed here, with more acupuncture sessions during the week since the frequency of sessions influences the response of the central nervous system.

\section{ACKNOWLEDGEMENTS}

We thank Haras Nossa Senhora Aparecida and Sítio Santana for supply of animal subjects. This study was financed in part by the Coordenação de Aperfeiçoamento de Pessoal de Nível Superior - Brasil (CAPES) - Finance Code 001.

\section{BIOETHICS AND BIOSSECURITY COMMITTEE APPROVAL}

Protocol No. 7328131119/2019.

DECLARATION OF CONFLICT OF
INTEREST

The authors declare no conflict of interest. The founding sponsors had no role in the design of the study, in the collection, analyses, or interpretation of data, in the writing of the manuscript, and in the decision to publish the results.

\section{AUTHORS' CONTRIBUTIONS}

DBC, ICT and TLR conceived and designed experiments. TLR, LLSN, AMO and VHLS performed the experiments. DBC and ICT supervised and coordinated the animal experiments. TLR performed statistical analyses of experimental data and prepared the draft of the manuscript. All authors critically revised the manuscript and approved of the final version.

\section{REFERENCES}

BAUM, J., et al. Assessment of intraocular pressure by palpation. American Journal of Ophthalmology, v.119, n.5, p.650-651, 1995. Available from: <https://www.sciencedirect.com/science/ article/pii/S0002939414702272?via\%3Dihub>. Accessed: Mar. 30, 2021. doi: 10.1016/S0002-9394(14)70227-2.

BENSKY, D. Introduction to Chinese medicine. In: Acupuncture: A comprehensive text. Seattle: Eastland Press, 1981. p.1-30.

CARIELLO, A. J. et al. Effect of electroacupuncture to prevent selenite-induced cataract in Wistar rats. Arquivos Brasileiros de Oftalmologia, v.269, n.3, p.299-303, 2006. Available from: $<$ http://www.scielo.br/scielo.php?script=sci arttext\&pid=S000427492006000300003\&lng=en\&nrm=iso $>$. Accessed: Mar. 10, 2018. doi: 10.1590/S0004-27492006000300003.

CASTILlO, B, M, J. How to promote and preserve eyelid health. Clinical Ophtalmology, v.6, p.1689-1698, 2012. Available from: $<$ https://pubmed.ncbi.nlm.nih.gov/23118519/>. Accessed: Mar. 30, 2021. doi: 10.2147/OPTH.S33133.

CHI-HO, T. et al. The mechanism of aqueous humour formation. Clinical \& Experimental Optometry, v.85, n.6, p.335-349, 2002. Available from: <https://pubmed.ncbi.nlm.nih.gov/12452784/>. Accessed: Mar. 30, 2021. doi: 10.1111/j.1444-0938.2002. tb02384.x. 
CHO, S. J.; KIM, O. Acupuncture treatment for idiopathic Horner's syndrome in a dog. Journal of Veterinary Science, v.9, n.1, p.117119, 2008. Available from: <https://www.ncbi.nlm.nih.gov/pmc/ articles/PMC2839107/\#> Accessed: Feb. 10, 2019. doi: 10.4142/ jvs.2008.9.1.117.

CHU, T. C.; POTTER, D. E. Ocular hypotension induced by electroacupuncture. Journal of Ocular Pharmacology and Therapeutics, v.18, n.4, p.293-305, 2002. Available from: $<$ https://www.researchgate.net/publication/11166326_Ocular Hypotension Induced by Electroacupuncture $>$. Accessed: Feb. 10, 2019. doi: $10.1089 / 10807680260218461$.

CRISPIN, S. M. Tear-deficient and evaporative dry eye syndromes of the horse. Veterinary Ophthalmology, v.3, n.2-3, p.87-92, 2000. Available from: <https://onlinelibrary.wiley.com/doi/epdf/1 0.1046/j.1463-5224.2000.3230087.x>. Accessed: Mar. 18, 2018. doi: 10.1046/j.1463-5224.2000.00112.x.

ELIASON, K. et al. Acupuncture treatment for dry eye. Medical Acupuncture, v.19, n.1, p.25-28, 2007. Available from: $<$ https:// go-gale.ez15.periodicos.capes.gov.br/ps/i.do?id=GALE\%7CA19 $1766828 \& \mathrm{v}=2.1 \& \mathrm{u}=$ capes $\& \mathrm{it}=\mathrm{r} \& \mathrm{p}=\mathrm{AONE} \& \mathrm{sw}=\mathrm{w}>$. Accessed: Mar. 18, 2018. doi: 10.1089/acu.2006.504

ERNST, E. Acupuncture - a critical analysis. Journal of Internal Medicine, v.259, n.2, p.125-137, 2006. Available from: <https:// onlinelibrary.wiley.com/doi/full/10.1111/j.1365-2796.2005.01584 x>.Accessed:Mar. 18,2018. doi: 10.1111/j.1365-2796.2005.01584.x.

ERNST, E. et al. Acupuncture: its evidence-base is changing The American Journal of Chinese Medicine, v.35, n.1, p.2125, 2007. Available from: <https:/www.worldscientific.com/doi/ epdf/10.1142/S0192415X07004588> Accessed: Mar. 18, 2018 doi: 10.1142/S0192415X07004588.

FARIA, A. B.; SCOGNAMILLO-SZABÓ, M. V. R. Acupuntura Veterinária: Conceitos e Técnicas - Revisão. Ars Veterinaria, v.24, n.2, p.83-91, 2008. Available from: $<$ http://arsveterinaria.org br/index.php/ars/article/view/184/152>. Accessed: Mar. 18, 2018.

GHAFFARI, M. S. et al. Effect of topical $1 \%$ tropicamide on Schirmer tear test results in clinically normal horses. Veterinary Ophthalmology, v.12, n.6, p.369-371, 2009. Available from: <https://onlinelibrary.wiley.com/doi/epdf/10.1 111/j.1463-5224.2009.00734.x>. Accessed: Mar. 18, 2018. doi: 10.1111/j.1463-5224.2009.00734.x.

GONG, L.; SUN, X. Treatment of intractable dry eyes: tear secretion increase and morphological changes of the lacrimal gland of rabbit after acupuncture. Acupuncture \& Electrotherapeutics Research, v.32, n.3-4, p.223-233, 2007. Available from: < https://www-periodicos-capes-gov-br.ez15.periodicos. capes.gov.br/index.php? option $=$ com pmetabusca $\& m n=88 \&$ $\mathrm{smn}=88 \&$ type $=\mathrm{m} \&$ metalib $=$ aHR0cHM6Ly9ybnAtcHJpbW 8

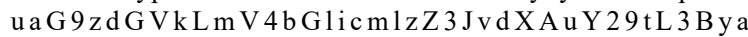
W1vX2xpYnJhcnkvbGlid2ViL2FjdGlvbi9zZ WFyY2guZG8/ dmlkPUNBUEVTX1Yx\&It Itemid=124>. Accessed: Jul. 20, 2019. doi: 10.3727/036012907815844011.

GRAHN, B. H.; STOREY, E. S. Lacrimomimetics and lacrimostimulants. The Veterinary Clinics of North America. Small Animal Practice, v.34, n.3, p.739-753, 2004. Available from: <https://www.sciencedirect.com/ science/article/pii/S0195561603001876?via\%3Dihub>. Accessed: Mar. 18, 2018. doi: 10.1016/j.cvsm.2003.12.009.
HAMOR, R. E. et al. Evaluation of results for Schirmer tear tests conducted with and without application of a topical anesthetic in clinically normal dogs of 5 breeds. American Journal of Veterinary Research, v.61, p.1422-1425, 2005. Available from: <https://avmajournals.avma.org/doi/10.2460/ ajvr.2000.61.1422?url_ver=Z39.88-2003\&rfr_id=ori:rid:crossref. org\&rfr_dat $=$ cr_pub $\% \overline{2} 0 \% 200$ pubmed $>$. Accessed: Jul. 20, 2019. doi: $10 . \overline{2} 460 /$ ajvr.2000.61.1422.

KIM, M. S. et al. Effect of acupuncture on intraocular pressure in normal dogs. The Journal of Veterinary Medical Science, v.67, n.12, p.1281-1282, 2005. Available from: $<$ https://www.jstage.jst. go.jp/article/jvms/67/12/67 12 1281/ pdf/-char/en>. Accessed: Mar. 18, 2018. doi: 10.1292/jvms.67.1281.

KIM, Y. S. et al. The practice of Korean medicine: an overview of clinical trials in acupuncture. Evidence-Based Complementary and Alternative Medicine, v.2, n.3, p.325352, 2005. Available from: <https://www.ncbi.nlm.nih.gov/pmc/ articles/PMC1193543/>. Accessed: Mar. 30, 2021. doi: 10.1292/ jvms.67.1281

KURUSU, M. et al. Acupuncture for patients with glaucoma. Explore (NY), v.1, n.5, p.372-376, 2005. Available from: $<$ https://www.sciencedirect.com/science/article/pii/ S1550830705002995?via\%3Dihub> Accessed: Feb. 10, 2019. doi: 10.1016/j.explore.2005.06.007.

LIN, J. H. et al. Sustainable veterinary medicine for the new era. Revue Scientifique et Technique, v.22, n.3, p.949-964, 2003. Available from: <https://doc.oie.int/dyn/portal/index. seam page $=$ alo\&aloId $=30262>$. Accessed: Mar. 30, 2021. doi: 10.20506/rst.22.3.1451.

LIN,Y.C.Perioperative usage ofacupuncture.PediatricAnesthesia, v. 16, n. 3, p.231-235, 2006. Available from: <https://onlinelibrary. wiley.com/doi/epdf/10.1111/j.1460-9592.2005.01829.x>. Accessed: Mar. 18, 2018. doi: 10.1111/j.1460-9592.2005.01829.x.

MACIOCIA, G. Os fundamentos da Medicina Chinesa: um texto abrangente para acupunturistas e fitoterapeutas. São Paulo: Roca, 2007.

MCLELLAN, G. L.; ARCHER, F. J. Corneal stromal sequestration and keratoconjunctivitis sicca in a horse. Veterinary Ophthalmology, v.3, n.2-3, p.207-212, 2000. Available from: <https://onlinelibrary.wiley.com/doi/epdf/10.10 46/j.1463-5224.2000.3230207.x>. Accessed: Mar. 18, 2018. doi: 10.1046/j.1463-5224.2000.3230207.x.

PETERS, D. et al. Lifetime risk of blindness in open-angle glaucoma. American Journal of Ophthalmology, v.156, n.4, p.724-730, 2013. Available from: <https://www.sciencedirect.com/ science/article/pii/S0002939413003644?via\%3Dihub>. Accessed: Feb. 10, 2019. doi: 10.1016/j.ajo.2013.05.027.

RHEE, D. J. et al. Prevalence of the use of complementary and alternative medicine for glaucoma. Ophthalmology, v.109, n.3, p.438-443, 2002. Available from: $<$ https://www.sciencedirect.com/ science/article/pii/S0161642001010302?via\%3Dihub>. Accessed: Feb. 10, 2019. doi: 10.1016/S0161-6420(01)01030-2.

SCOGNAMILLO-SZABÓ, M. V. R.; BECHARA, G. $\mathrm{H}$. Acupuntura: histórico, bases teóricas e sua aplicação em Medicina Veterinária. Ciência Rural, v.40, n.2, p.491-500, 2010. Available from: <https:/www.scielo.br/scielo.php?pid=S0103- 
$84782010000200040 \&$ script $=$ sci_abstract $\&$ tlng $=$ pt $>$. Accessed: Feb. 10, 2019. doi: 10.1590/S0103-84782010005000004.

SILVA, J. C. et al. Efectos de la acupuntura sobre la secreción lagrimal (acupuntos BL-2, TH-23 y Tai-Yang) y la presión intraocular (acupuntos LI-4, LIV-3 y GB-37) en perros de raza Beagle. Archivos de Medicina Veterinaria, v.47, n.3, p.365-373, 2015. Available from: $<$ https://scielo.conicyt.cl/scielo.php?script=sci_abstract\&pid=S0301732X2015000300014\&lng=e\&nrm=iso $>$. Accessed: Mar. 10, 2018. doi: 10.4067/S0301-732X2015000300014.

TANGJITJAROEN, W. et al. Equine acupuncture research: an update. Journal of Equine Veterinary Science, v.29, n.9, p.698-709, 2009. Available from: <https://www-sciencedirect.ez15.periodicos. capes.gov.br/science/article/pii/S0737080609005760?via=ihu> Accessed: Feb. 10, 2019. doi: 10.1016/j.jevs.2009.07.018.

TAYLOR, D. Alternative eye care. British Journal of Ophthalmology, v.85, n.7, p.767-768, 2001. Available from: $<$ https://bjo.bmj.com/content/85/7/767>. Accessed: Mar. 10, 2018. doi: $10.1136 /$ bjo.85.7.767.
SMITH, P.J et al. Unconventional aqueous humor outflow of microspheres perfused in the equine eye. American of Journal Veterinary Research, v.47, n.11, p.2445-2453, 1986. Available from: <https://pubmed.ncbi.nlm.nih.gov/3789508/>. Accessed: Apr. 30, 2021. doi: 10.1016/j.exer.2008.12.012.

TSENG, K. L. et al. A clinical study of acupuncture and SSP (silver spike point) electro-therapy for dry eye syndrome. The American Journal of Chinese Medicine, v.34, n.2, p.197-206, 2006. Available from: <https:/www.worldscientific.com/doi/ epdf/10.1142/S0192415X0600376X>. Accessed: Feb. 10, 2019. doi: 10.1142/S0192415X0600376X.

ULETT, G. A. et al. Electroacupuncture: mechanisms and clinical application. Biological Psychiatry, v.44, n.2, p.129-138, 1998. Available from: <https://www.sciencedirect.com/science/article/ pii/S0006322397003946?via\%3Dihub>. Accessed: Mar. 18, 2018. doi: 10.1016/S0006-3223(97)00394-6.

XIE, H.; PREAST, V. Xie's Veterinary Acupunture. 1 ed. Iowa, USA: Blackwell Publishing, 2007. 